Lev Chernyak ${ }^{1 *}$, Liubov Melnyk ${ }^{1}$, Natalia Dorogan ${ }^{1}$, Dmytiy Gluschenko ${ }^{1}$, Petro Varschavets ${ }^{2}$

${ }^{1}$ National Technical University of Ukraine "Igor Sikorsky", Kyiv Polytechnic Institute, Kyiv, Ukraine, ${ }^{2}$ LLC «FASAD», Kyiv, Ukraine
Scientific paper

ISSN 0351-9465, E-ISSN 2466-2585

UDC: $666.9 .05: 662.613 .12: 641.522 .4$

https://doi.org/10.5937/zasmat2103228C

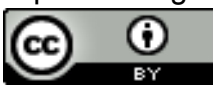

Zastita Materijala $62(3)$

228 - 234 (2021)

\title{
Application of perlite and waste of paper production for manufacturing of cement clinker
}

\begin{abstract}
The possibility of making cement clinker with the integrated use of natural raw materials of volcanic origin and waste from paper production (scope) has been studied. The analysis of the dependence of the composition of the raw mixture based on the system chalk - perlite - scope on the specified characteristics of cement using the specially developed computer program "Clinker" has been carried out. The composition of the initial mixture for the manufacturing of cement clinker was determined with a quantitative ratio of perlite: scope $=1: 3.5$ has been investigated. The features of the formation of the phase composition and properties of the binder during the firing of the raw mixture in the range of maximum temperatures $1200-1400^{\circ} \mathrm{C}$ are shown.
\end{abstract}

Keywords: cement, clinker, perlite, scope, mixture raw material, composition, firing, phases crystalline, properties.

\section{1, INTRODUCTION}

The expansion and increase in efficiency of production of silicate materials is associated with the integrated use of raw materials of natural and technogenic origin [1-4]. The practical solution of such problems requires the corresponding development of the scientific and technical foundations of chemical technology of silicates the determination of patterns regarding the influence of concentration of raw materials on structure formation and properties of the materials. In the direction of solving the problem of expanding the raw material base for production of mineral binders, this work has been done.

Rocks of volcanic origin are one of the sources of natural silicate raw materials [5-8]. Among the rocks of volcanic origin, perlite occupies a significant place in terms of distribution and reserves. Based on the peculiarities of the structure and attitude to heat treatment, the main direction of using this material was the manufacture of expanded perlite, which is used in construction and agriculture [9].

${ }^{*}$ Corresponding author: Lev Chernyak

E-mail: Ipchernyak@ukr.net

Paper received: 07. 08. 2021.

Paper accepted: 17. 08. 2021.

Paper is available on the website: www.idk.org.rs/journal
At the same time, increasing the efficiency of the existing open-pit mines requires expanding the areas of practical application of perlite. One of these promising areas can be the mass-intensive production of ceramics [10-12] and cements [13].

In the production of cement and concrete, waste from other industries is used, mostly blast furnace slag as a substitute for clinker when grinding cement $[8,14-16]$. Regarding raw material mixtures for production of clinker, a small amount (1.5-5.0 wt.\%) of iron-containing industrial waste pyrite cinders or red sludge is introduced into their composition as a fluxing additive.

In this regard, scope, an industrial waste formed in the production of paper and cardboard and is a mixture of cellulose fibers, dispersed organic and inorganic substances [17,18], is of considerable interest. Peculiarities of the composition and a certain calorific value of scope have determined the directions of known research and developments directed on its utilization in energy and agro-industrial complexes as well as for the manufacturing of building materials [19-21]. With regard of building materials, it is proposed to use scope as a filler in the manufacturing of heat and sound insulation boards and as a raw material component for the manufacturing of expanded clay and algoporite - expanded granular ceramic 
materials. However, the actual volumes of scope utilization do not correspond to the quantitative level of generation and accumulation of these industrial wastes. Based on this, increase in the use of scope as a man-made raw material in resource-intensive cement production is an urgent task of comprehensively addressing the issues of chemical technology of silicates and environmental protection.

Formulation of the problem. The results of the analysis of known data lead to the conclusion about the relevance and feasibility of scientific and technical solutions for the development of new compositions of mixtures with the integrated use of natural and man-made raw materials for the manufacture of cement clinker.

\section{EXPERIMENTAL PART}

The object of the study were raw material mixtures for the manufacturing of cement clinker based on the chalk - perlite - SCOPE system.

The raw material mixtures have been prepared by dispensing the components by mass, mixing and homogenizing in a ball mill, firing and milling of the final product in accordance with the modern technology of cement industry.

Samples of raw material mixtures have been burned in an oven during 15 hours on maximum temperature $1200-1400{ }^{\circ} \mathrm{C}$ keeping a hold at a maximum of 1.5 hours. All samples of the mixtures that have been compared were burned together to exclude the possibility of a difference in the degree of heat treatment.
Methods of physical - chemical analysis of silicate raw materials and of testing of properties of astringent substances which were used in this work included:

- chemical composition analysis using standardized procedures.

- X-ray diffraction analysis (powder like preparations) using a DRON-3M diffractometer (CuKa 1-2 radiation, voltage $40 \mathrm{kV}$, current 20 $\mathrm{mA}$, speed 2 degrees / $\mathrm{min}$ );

- determination of indicators of cement properties in accordance with current standards.

To determine the rational composition of the initial mixture varieties of raw materials were used:

- chalk of Zdolbuniv deposit of Rivne region;

- perlite of the Beregovo deposit of the Transcarpathia region;

- scope - waste of paper production at Kyiv Cardboard and Paper Factory.

Samples of raw materials differ significantly in genesis and composition.

Chalk and perlite are natural raw materials of sedimentary and volcanic origin, respectively, scope is a man-made raw material - waste of paper industry.

The chemical composition of the chalk sample is characterized by a predominant $\mathrm{CaO}$ content (55.0 wt.\%), perlite sample - a high content of $\mathrm{SiO}_{2}$ (72.1 wt.\%) by the quantitative ratio of $\mathrm{SiO}_{2}: \mathrm{Al}_{2} \mathrm{O}_{3}$ $=5.6$ and a significant amount of alkaline oxides $\mathrm{Na}_{2} \mathrm{O}+\mathrm{K}_{2} \mathrm{O}=8.1$ wt. \%, Table 1 .

Table 1. Chemical composition of raw materials

Tabela 1. Hemijski sastav sirovina

\begin{tabular}{|c|c|c|c|c|c|c|c|c|c|c|}
\hline Samples & $\mathrm{SiO}_{2}$ & $\mathrm{Al}_{2} \mathrm{O}_{3}$ & $\mathrm{Fe}_{2} \mathrm{O}_{3}$ & $\mathrm{TiO}_{2}$ & $\mathrm{CaO}$ & $\mathrm{MgO}$ & $\mathrm{SO}_{3}$ & $\mathrm{Na}_{2} \mathrm{O}$ & $\mathrm{K}_{2} \mathrm{O}$ & $\mathrm{LOI}$ \\
\hline chalk & 0.77 & 0.25 & 0.13 & - & 55.0 & 0.25 & 0.08 & - & - & 43.49 \\
\hline perlite & 72.08 & 12.92 & 1.50 & 0.90 & 0.88 & 0.63 & - & 3.76 & 4.33 & 3.0 \\
\hline scope & 10.23 & 7.80 & 0.56 & 0.27 & 25.77 & 1.27 & 0.20 & 0.33 & 0.17 & 50.41 \\
\hline
\end{tabular}

The scope sample differs from perlite by a larger amount of $\mathrm{CaO}$ (25.8 wt.\%), a lower content of $\mathrm{SiO}_{2}$ with quantitative ratio of $\mathrm{SiO}_{2}: \mathrm{Al}_{2} \mathrm{O}_{3}=1.3$. Quantitative ratios of oxides $\mathrm{CaO}: \mathrm{SiO}_{2}=2.5$, $\mathrm{CaO}: \mathrm{Al}_{2} \mathrm{O}_{3}=3.3, \mathrm{CaO}: \mathrm{SiO}_{2}: \mathrm{Al}_{2} \mathrm{O}_{3}=3.3: 1.4: 1$, which determine the potential phase formation during firing of raw materials.
The mineralogical composition of the chalk is characterized by a predominant content of calcite; perlite - by a developed glass phase with crystalline inclusions of quartz and feldspar; scope is marked by the presence of crystalline phases, mainly - calcite, quartz, kaolinite, Figure 1 and 2 . 


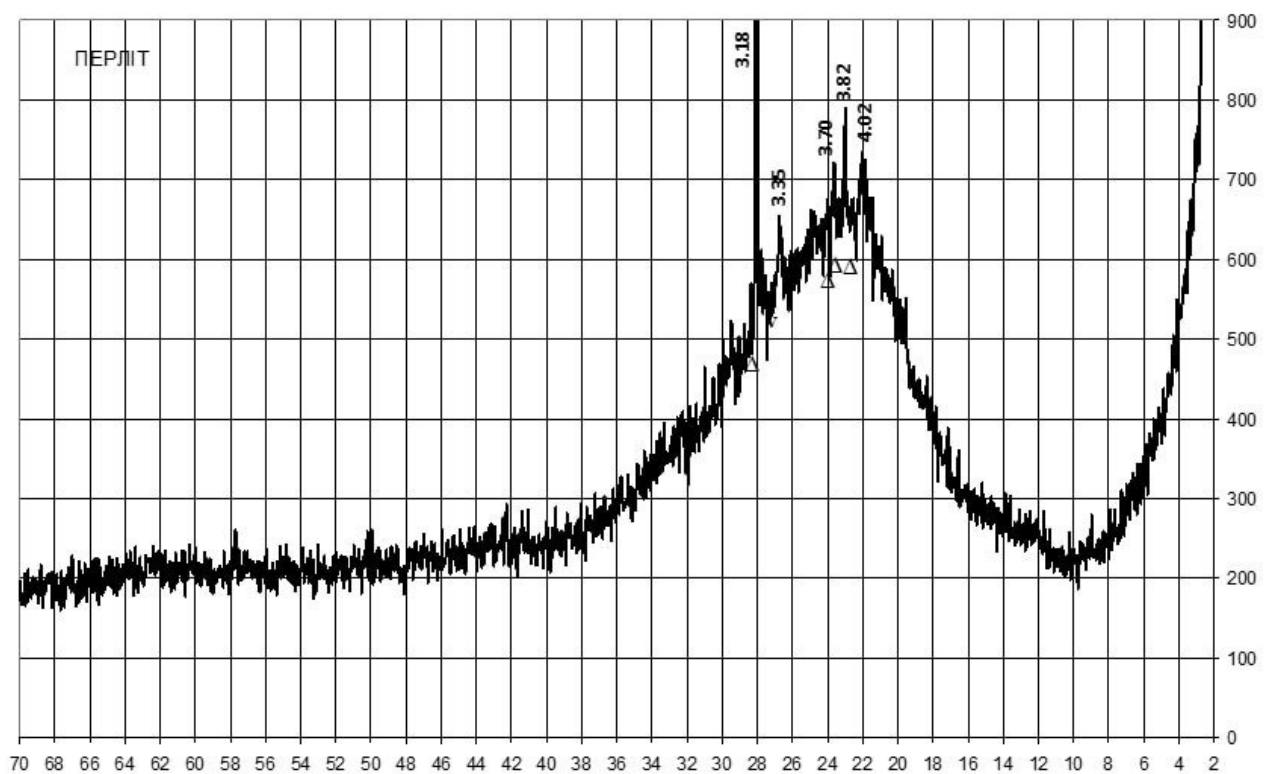

Figure 1. X-ray diffraction of Transcarpathian perlite: $v$ - $\beta$-quartz, $\Delta$ - feldspar

Slika 1. Rendgenska difrakcija zakarpatskog perlita: $v$ - $\beta$-kvarc, $\Delta$-feldspat

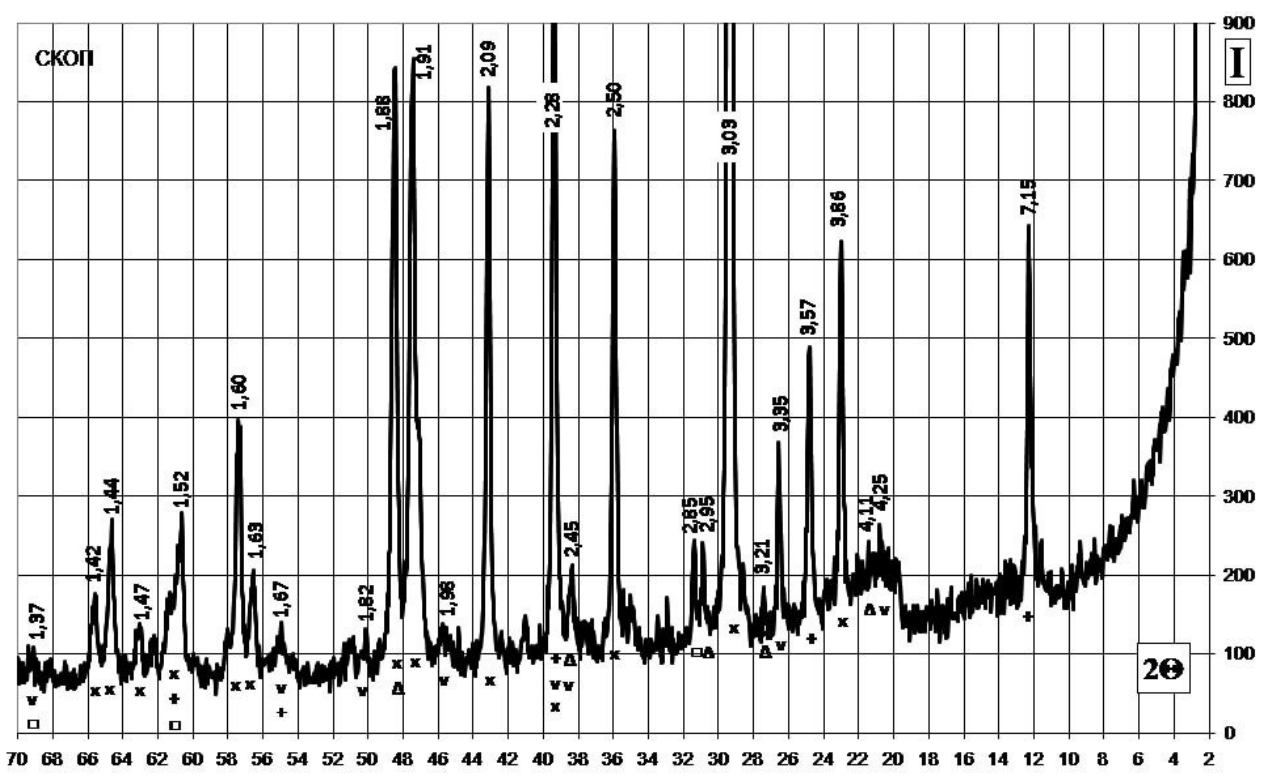

Figure 2. X-ray diffraction of scope: $v$ - $\beta$-quartz, +- kaolinite, $x$-calcite, $\Delta$-feldspar

Slika 2. Rendgenska difrakcija opsega: $v$ - $\beta$-kvarc, +- kaolinit, $x$-kalcit, $\Delta$-feldspar

Calculations and analysis of the composition of raw materials for the manufacturing of cement clinker have been performed using the computer program "CLINKER" [22] according to known recommendations for numerical values of the saturation coefficient of SF, silica $n$ and alumina $p$ modules.

The analysis of the obtained results has shown that in the recommended range of SF the possible concentration of perlite in the composition of the raw material mixtures significantly depends on the varieties and the quantitative ratio of other components.

According to the results of computer calculations in binary mixtures based on chalk at the recommended number of saturation coefficient $\mathrm{SF}=0.90$, the possible content of perlite is about 19 wt. \%, and scope - 79.5 wt. \%, however, the number of silica and alumina modules do not correspond to the recommended $n=1.9-3.0$ and $\mathrm{p}=0.90-2.0$ for cement clinker,Table 2 . 
Table 2. Composition of binary mixtures and characteristics of clinker

Tabela 2. Sastav binarnih smeša i karakteristike klinkera

\begin{tabular}{|c|c|c|c|c|c|c|}
\hline \multirow{2}{*}{ System } & \multicolumn{3}{|c|}{ Composition of initial mixture, wt. \% } & \multicolumn{3}{c|}{ Clinker characteristics } \\
\cline { 2 - 7 } & chalk & perlite & scope & SF & $\mathrm{n}$ & $\mathrm{p}$ \\
\hline chalk - perlite & 80.88 & 19.12 & - & 0.90 & 4.70 & 6.79 \\
\hline chalk - scope & 20.48 & - & 79.52 & 0.90 & 1.23 & 13.20 \\
\hline
\end{tabular}

When using 3-component mixtures based on the system of chalk-perlite - scope on the saturation coefficient $\mathrm{SF}=0.80-0.95$ binder material corresponds to the recommended values of the increased alumina modulus. In the range of values of the saturation coefficient $S F=0.80-0.95$ at $n=2.5$ the possible content of perlite is 10.1-11.1 wt. \%, and scope 35.1-39.0 wt. \%, Figure 3.

silica modulus $(n=2.0-3.5)$, but also has an

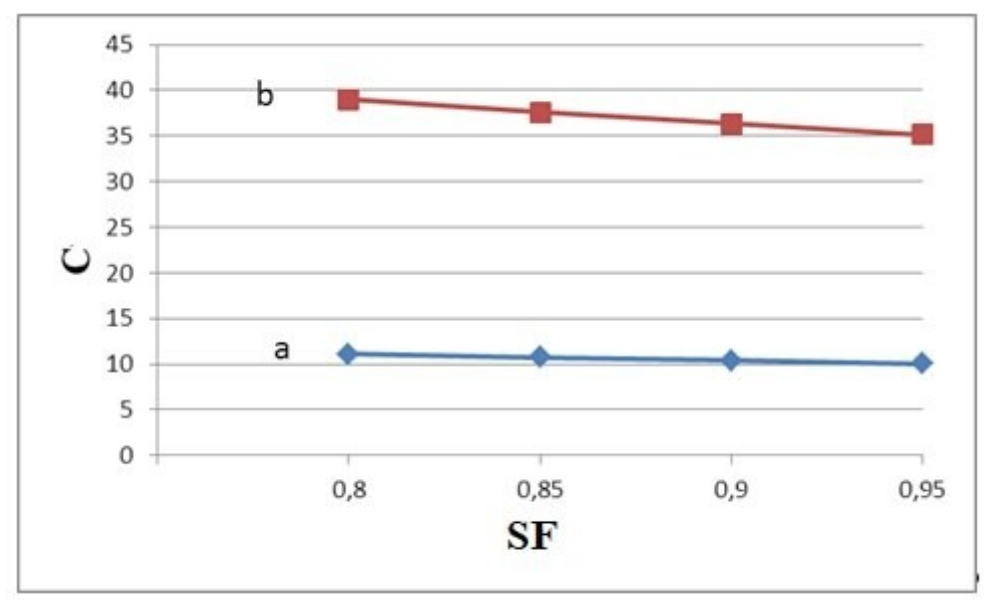

Figure 3. The dependence of perlite (a) and scope (b) content in the mixture on basis of chalk from saturation factor SF of clinker at silica module $n=2.5$

Slika 3. Zavisnost sadržaja perlita (a) i obima (b) u smeši na osnovu krede od faktora zasićenja SF klinkera na modulu silicijuma $n=2,5$

The raw material mixture 09-3 was selected for the study, which is characterized by a high content of man-made raw materials at a quantitative ratio of perlite : scope $=1: 3.5$, Table 3 , and the chemical composition - the ratio of $\mathrm{SiO}_{2}: \mathrm{Al}_{2} \mathrm{O}_{3}=2.6$, $\mathrm{CaO}: \mathrm{SiO}_{2}=3.1, \mathrm{CaO}: \mathrm{Al}_{2} \mathrm{O}_{3}=8.7$ with an iron oxide content of $0.45 \%$, Table 4 .
Table 3. Composition of raw mixtures

Tabela 3. Sastav sirovih smeša

\begin{tabular}{|c|c|c|c|}
\hline \multirow{2}{*}{ Code of mixture } & \multicolumn{3}{|c|}{ Quantity of components, mass \% } \\
\cline { 2 - 4 } & chalk & perlite & scope \\
\hline $09-3$ & 53.3 & 10.4 & 36.3 \\
\hline
\end{tabular}

Table 4. Chemical composition of raw mixture

Tabela 4. Hemijski sastav sirove smeše

\begin{tabular}{|c|c|c|c|c|c|c|c|}
\hline \multirow{2}{*}{ Code of mixture } & \multicolumn{7}{|c|}{ Oxides content, \% } \\
\cline { 2 - 10 } & $\mathrm{SiO}_{2}$ & $\mathrm{Al}_{2} \mathrm{O}_{3}$ & $\mathrm{Fe}_{2} \mathrm{O}_{3}$ & $\mathrm{CaO}$ & $\mathrm{MgO}$ & $\mathrm{SO}_{3}$ & $\mathrm{LOI}$ \\
\hline $09-3$ & 12.49 & 4.54 & 0.45 & 39.13 & 0.68 & 0.23 & 42.48 \\
\hline
\end{tabular}

Table 5. Design characteristics of clinker

Tabela 5. Karakteristike dizajna klinkera

\begin{tabular}{|c|c|c|c|c|c|c|c|}
\hline \multirow{2}{*}{ Code of sample } & \multicolumn{3}{|c|}{ Clinker characteristics } & \multicolumn{4}{c|}{ Crystalline phases content, \% } \\
\cline { 2 - 8 } & SF & $\mathrm{n}$ & $\mathrm{p}$ & $\mathrm{C} 3 \mathrm{~S}$ & $\mathrm{C} 2 \mathrm{~S}$ & $\mathrm{C} 3 \mathrm{~A}$ & C4AF \\
\hline $09-3$ & 0.90 & 2.50 & 10.13 & 57.17 & 18.48 & 19.61 & 2.35 \\
\hline
\end{tabular}


The specified quantitative ratio of components and chemical composition correspond to the following design characteristics of cement clinker, Table 5.
X-ray phase analysis of sample 09-3 allowed us to investigate the process of clinker phase formation in the range of maximum firing temperatures $1200-1400^{\circ} \mathrm{C}$, Figure 4 and 5 .

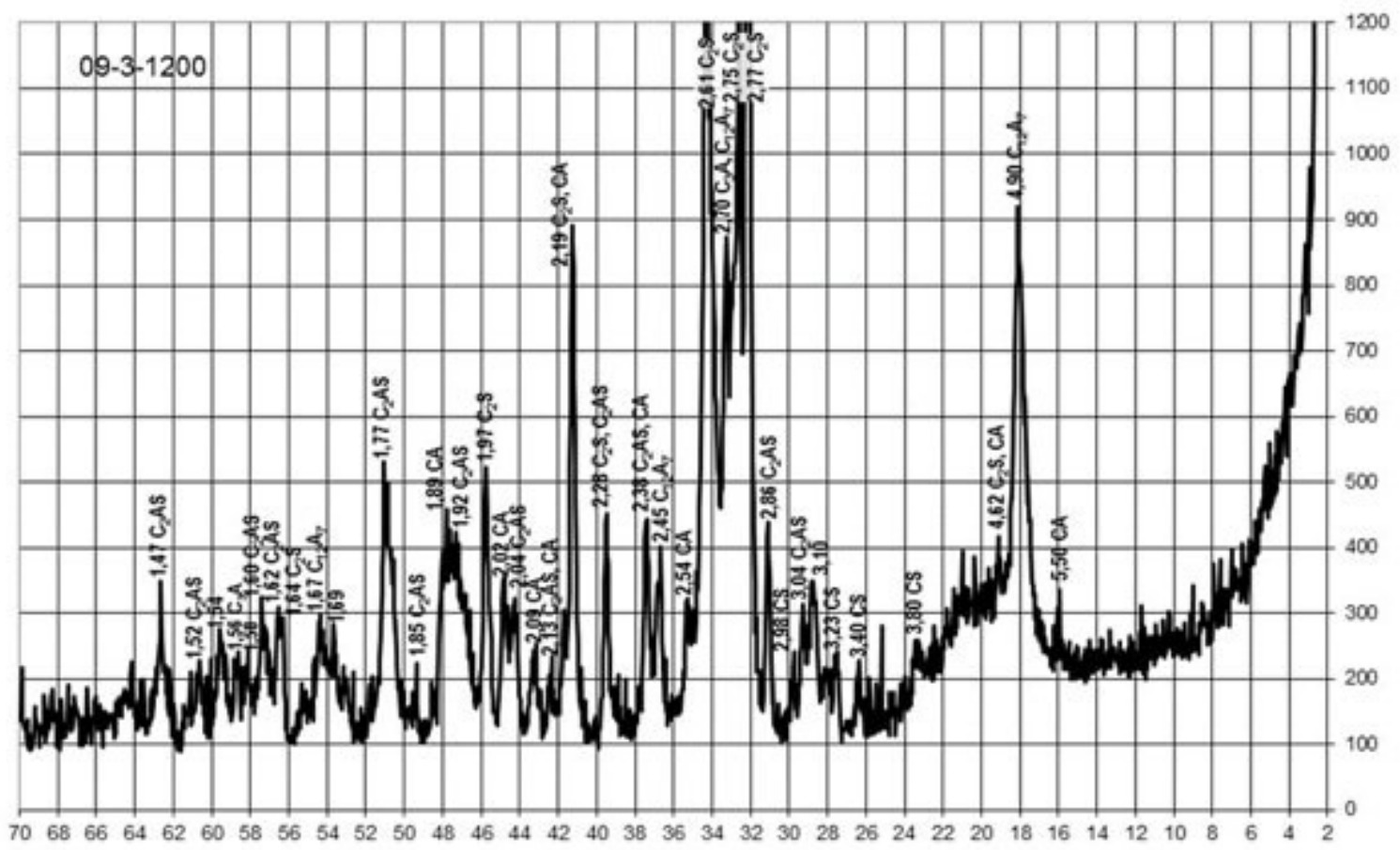

Figure 4. X-ray diffraction of sample 09-3 $\left(1200^{\circ} \mathrm{C}\right)$

Slika 4. Rendgenska difrakcija uzorka 09-3 (1200 $\left.{ }^{\circ} \mathrm{C}\right)$

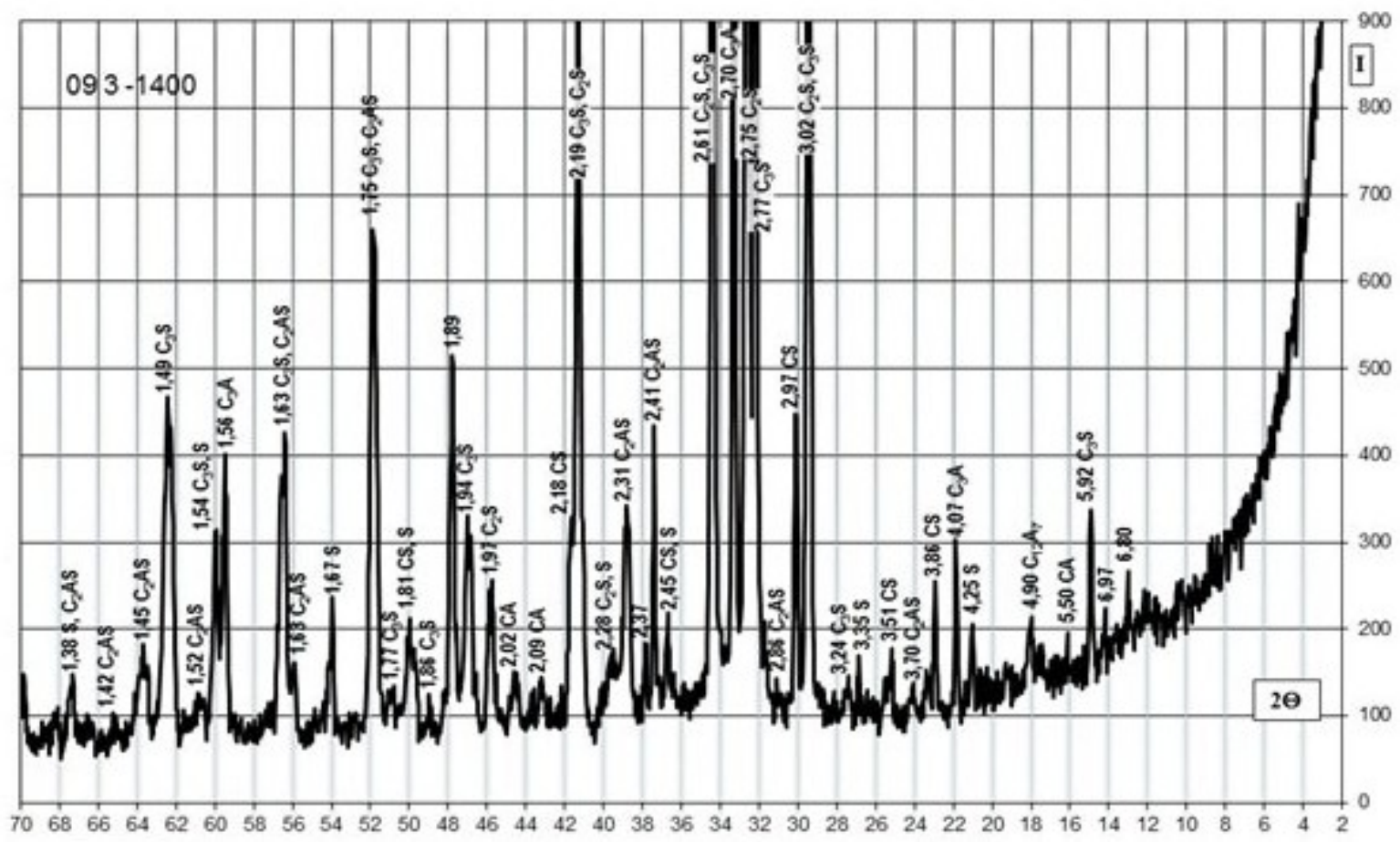

Figure 5. X-ray diffraction of sample 09-3 $\left(1400^{\circ} \mathrm{C}\right)$

Slika 5. Rendgenska difrakcija uzorka 09-3 $\left(1400^{\circ} \mathrm{C}\right)$ 
It is established that with increasing of the maximum firing temperature from 1200 to $1400{ }^{\circ} \mathrm{C}$ the material differs:

- for the crystalline phases of calcium silicates the formation of $\mathrm{C}_{3} \mathrm{~S}(1.63,2.19,3.02 \AA)$ and the intensification of the development of CS wollastonite $(2.97 \AA)$;

- relative to the crystalline phases of calcium aluminosilicates - much less formation of $\mathrm{C}_{2} \mathrm{AS}$ gelenite $(2.86,1.92,1.77 \AA)$;

- relative to the crystalline phases of calcium aluminates - significant formation of $\mathrm{C}_{3} \mathrm{~A}(2.70$ $\AA)$; when reducing the amount of CA (2.54, $5.50 \AA$ ) and mayenite $C_{12} A_{7}(4.90 \AA)$;

- $\quad$ more crystalline quartz $(3.35,4.25 \AA)$.

According to the classification of DSTU B V.2791-99 on the rate of hardening after firing at a maximum temperature of $120{ }^{\circ} \mathrm{C}$ sample $09-3$ belongs to the group of fast-setting (starting time from 15 to 45 minutes), the characteristic representatives of which are anhydrite and alumina cement, table 6 .

\section{Table 6. Properties of mineral astringent material}

Tabela 6. Svojstva mineralnog astrigentnog materijala

\begin{tabular}{|c|c|c|}
\hline \multirow{2}{*}{ Properties } & \multicolumn{2}{|c|}{$\begin{array}{c}\text { Maximum firing } \\
\text { temperature, }\end{array}$} \\
\cline { 2 - 3 } & 1200 & 1400 \\
\hline $\begin{array}{c}\text { Finess of grinding, sieve } \\
\text { residue no. 008, mass. \% }\end{array}$ & 10 & 10 \\
\hline Initial setting time, min & 5 & 90 \\
\hline Final setting time, min & 35 & 150 \\
\hline $\begin{array}{c}\text { Compressive strength } \\
\text { (28 days), MPa }\end{array}$ & 27.4 & 39.2 \\
\hline
\end{tabular}

After firing to a maximum temperature of 1400 ${ }^{\circ} \mathrm{C}$ samples 09-3 belong to the group of normalizing (starting time from 45 minutes to 2 hours), the typical representatives of which are Portland cement and slag Portland cement.

\section{CONCLUSIONS}

1. Comprehensive use of perlite and waste of paper production contributes to expansion of the raw material base of cement production, solving problems of resource saving and chemical technology of silicates.

2. The possible content of Transcarpathian perlite and scope in composition of raw materials for the manufacturing of cement clinker is 31.5 to 46.7 wt. \% when varying their quantitative ratio from $1: 1$ to $1: 3.5$.
3. According to X-ray phase analysis and technological testing, the peculiarities of the development of crystalline phases and binder properties of material in the range of $1200-1400{ }^{\circ} \mathrm{C}$ of the maximum firing temperatures of clinker from a mixture using perlite and scope have been determined.

\section{REFERENCES}

[1] И.Б.Удачкин, А.А.Пащенко, Л-П.Черняк, П.В.Захарченко, А.С.Семидидько, Е.А.Мясникова (1988) Комплексное развитие сырьевой базы промышленности строительных материалов, Будівельник, К., с.104.

[2] S.Allen, T.David, G.Benmanesh, A.Nasrin (1994) Wastes as Raw Materials. The Greening of Industrial Ecosystems, National Academy Press, Washington, p.69-89.

[3] Л.И.Дворкин, О.Л.Дворкин (2007) Строительные материалы из отходов промышленности: учебносправочное пособие, Феникс, Ростов н/Д, с.363.

[4] M.Ramesh, K.S.Karthic, T.Karthikeyan, A.Kumaravel (2014) Construction materials from industrial wastes-a review of current practices, International Journal of Environmental Research and Development, 4(4), 317-324.

[5] В.В.Козырев, Ю.С.Спешнев, Л.В.Ерохина (1975) Вулканические породы как сырье для керамической промышленности, ВНИИЭСМ, М., c. 45 .

[6] Е.Л.Гуменюк, Р.М.Зайонц, Л.П.Черняк (1980) Структурообразование и свойства некоторых пород вулканического происхождения, Исследования в области технологии производства новых видов керамических изделий, Стройиздат, М., с.109-117.

[7] Aa.K.Waswa, D.M.Nyaberi (2009) Evalution of volcanic rocks of Nairobi area for use as raw materials in the construction and cement industry, Conference: Geological Society of Kenya.

[8] А.А.Пащенко, Е.А.Мясникова, Е.Р.Евсютин (1990) Энергосберегающие и безотходные технологии получения вяжущих веществ, Вища школа, К., с.223.

[9] Л.В.Алексеева, С.Ю.Нациевский (2013) Опыт применения вспученного перлита в строительстве, Строительные материалы и изделия, 5-6, 62-64.

[10] Л.Л.Кошляк, В.В.Калиновский (1990) Производство изделий строительной керамики, Высшая школа, М., с.207.

[11] K.Kayacı (2020) The use of perlite as flux in the production of porcelain stoneware tiles, Boletín de la Sociedad Española de Cerámica y Vidrio.

[12] T.K.Erdem, Ç.Mera, I.M.Tokyay, T.Y.Erdoğan (2007) Use of perlite as a pozzolanic addition in producing blended cements, Cement and Concrete Composites, 29(1), 13-21. 
[13] B.Tarhan, M.Tarhan (2021) Utilization of perlite as an alternative raw material in the production of ceramic sanitaryware, J.Therm.Anal.Calorim., https://doi.org/10.1007/s10973-021-10784-5

[14] S.N.Ghosh (2003) Advances in Cement Technology: Chemistry, Manufacture and Testing, Taylor \& Francis, p.828.

[15] В.К.Классен, И.Н.Борисов, В.Е.Мануйлов; под общ. ред. В.К. Классена (2008) Техногенные материалы в производстве цемента: монография, Изд-во БГТУ, Белгород, с.126.

[16] B.N.Winter (2012) Understanding Cement, WHD Microanalysis Consultants Ltd, p.206.

[17] M.C.Monte, E.Fuente, A.Blanco, C.Negro (2009) Waste management from pulp and paper production in the European Union, Waste Management, 29(1), 293-308.

[18] L.Simao, D.Hotza, F.Raupp-Pereira, J.A.Labrincha, 0.R.K.Montedo (2018) Wastes from pulp and paper mills - a review of generation and recycling alternatives, Cerâmica, 64( 371), 443-453.

[19] M.Gopal (1986) The scope for utilizing jute wastes as raw materials in various industries: A review, Agricultural Wastes, 15(2), 149-158.

[20] Б.Баталин, И.Козлов (2004) Строительные материалы на основе скопа - отхода целлюлозно-бумажной промышленности, Строительные материалы, 1, 42-43.

[21] Л.П.Черняк, П.Г.Варщавець, Н.О.Дорогань, О.М. Шнирук (2019) Мінеральний в'яжучий матеріал із використанням відходів паперового виробництва, Керамика: наука и жизнь, 3(44), 16 - 22.

[22] В.А.Свідерський, Л.П.Черняк, Н.О.Дорогань, А.С.Сорока (2014) Програмне забезпечення технології портландцементу, Строительные материалы и изделия, 1(84), 16-17.

\section{IZVOD}

\section{PRIMENA PERLITA I OTPADA OD PROIZVODNJE PAPIRA ZA PROIZVODNJU CEMENTNOG CLINKERA}

Proučavana je mogućnost proizvodnje cementnog klinkera uz integrisanu upotrebu prirodnih sirovina vulkanskog porekla $i$ otpada iz proizvodnje papira (obim). Sprovedena je analiza zavisnosti sastava sirovinske smeše na osnovu sistemske krede - perlit - opsega od navedenih karakteristika cementa pomoću posebno razvijenog računarskog programa „Klinker“. Sastav početne smeše za proizvodnju cementnog klinkera određen je kvantitativnim odnosom perlita: opseg $=1:$ 3,5 je ispitan. Prikazane su karakteristike formiranja faznog sastava $i$ svojstva veziva tokom pečenja sirove smeše u opsegu maksimalnih temperatura $1200-1400^{\circ} \mathrm{C}$.

Ključne reči: cement, klinker, perlit, opseg, mešavina sirovina, sastav, pečenje, faze kristalne, svojstva.

\section{Naučni rad}

Rad primljen: 07. 08. 2021.

Rad prihvaćen: 17. 08. 2021.

Rad je dostupan na sajtu: www.idk.org.rs/casopis

(c) 2021 Authors. Published by Engineering Society for Corrosion. This article is an open access article distributed under the terms and conditions of the Creative Commons Attribution 4.0 International license (https://creativecommons.org/licenses/by/4.0/) 